\title{
From Cuba with Sugar: Chocolate, Rum and Iberian Nostalgia in Pennsylvania
}

\author{
By Galina Bakhtiarova*
}

\begin{abstract}
Introduction
In view of the changing relationship between Cuba and the USA, this paper explores the activities of the American entrepreneur Milton Hershey in Cuba during the first half of the twentieth century and a long-lasting impact that these activities left both on the Caribbean island and back home in Pennsylvania. Biographical, social, cultural and artistic issues will be discussed and analyzed. In search of control over a sugar supply for his chocolate production, American industrialist Milton Hershey spread his chocolate empire far beyond his Pennsylvania homestead. He built a highly efficient sugar mill and a refinery in Cuba that were eventually connected to the rum production during Prohibition. The Cuban enterprise included the first electric railroad on the island and a model town that mirrored Hershey, Pennsylvania. Back home, during the Great Depression, the profits from his Cuban enterprises allowed for a building of a luxury hotel in a nostalgic Spanish Revival Style. Even today as the Cuban economy and sugar industry are struggling, the Hotel Hershey in Pennsylvania stands as a monument to American imperialist nostalgia. Biographical data and background are followed by an overview of the Cuban - American relations at the beginning of the twentieth century. Milton Hershey's contribution to Cuban economy and social development are discussed in the Findings that are followed by an analysis of the connections with the Cuban rum industry at the time of Prohibition in the USA. Social impact on Cuban soil is followed by the discussion of the nostalgic recreation of the tropical paradise by designing the Hotel Hershey in the Iberian Revival style and its ever-lasting popularity in the USA.
\end{abstract}

\section{Biographical Data and Background}

Visitors to Hershey, Pennsylvania enjoy a great variety of entertainment centered on one of the most successful American enterprises of the twentieth century. Hersheypark, Hershey's Chocolate World, The Hershey Story Museum and the Hotel Hershey tell the story of the company and its founder, Milton Snavely Hershey (1857-1945), a native of Derry Township, Pennsylvania from different angles. A self-made man whose formal education ended in fourth

\footnotetext{
${ }^{*}$ Professor of Spanish, Western Connecticut State University, USA.
} 
grade, Milton Hershey achieved the American dream to its utmost success through a lifetime of tenacity and dedication. Among his many accomplishments, Milton Hershey was a pioneer who revolutionized the consumption of chocolate in the United States. A specific chocolate formula that he obtained after years of experimentation allowed him to manufacture an inexpensive product that he made readily available to consumers who previously could not afford the luxury of chocolate.

A savvy businessman, Milton Hershey not only built an industry from scratch, but in the vein of socially conscious entrepreneurs of the time, he supported the factory with a model town that satisfied the needs of his work force. The town boasted comfortable homes, modern amenities and entertainment facilities and certainly gave the owner complete control over the lives of his employees. An ever-busy entrepreneur and a philanthropist, at the height of his success, Hershey transferred all his personal wealth that included vast real estate and controlling interest in his company to the school for orphaned boys that he had previously founded. "Beneficent Jove" was an inscription on a cup presented to Hershey by his employees on the occasion of the tenth anniversary of the town of Hershey. The town to which he gave his own name had schools, outstanding sports and recreation facilities of his time, parks and gardens, its own department store, a zoo, a YMCA and a YWCA. In a utopian fashion, during the first decades of its existence, Hershey, Pennsylvania did not have a jail, a funeral home or a cemetery, even though there is no doubt that people died there.

In 1916, when his chocolate business and model town in Pennsylvania were booming, Milton Hershey switched his attention to sugar, a basic ingredient for chocolate. ${ }^{1}$ He traveled to Cuba, the major sugar producer at the time, and purchased several abandoned plantations and sugar mills. Soon he possessed a complete-cycle sugar producing facility and supported it by a factory town that, in a way, mirrored Hershey, Pennsylvania. To facilitate the transportation of sugar, Hershey built the first electric railroad on the island that is still in operation, sadly almost without any renovations. ${ }^{2}$

Hershey's biographer Michael D'Antonio ${ }^{3}$ notes that Milton Hershey led a kind of double life. A shrewd businessman with traditional and even

1. I would like to acknowledge Dr. Sofía Ruíz Alfaro, Franklin and Marshall College, Pennsylvania for pointing out to me the connection between Hershey and Cuba.

2. After Milton Hershey's death, the mill and refinery were sold in 1946 to the Cuban Atlantic Sugar Company from which they were expropriated after the Cuban revolution. The facility, renamed Central Camilo Cienfuegos, continued in business until 2002 when it was closed down together with many other centrales during the reorganization of Cuban industries.

3. Michael D'Antonio, Hershey: Milton Hershey's Extraordinary Life of Wealth, Empire and Utopian Dreams (New York: Simon \& Schuster, 2006), 142. 
conservative values while in his native Pennsylvania easily coexisted with a sophisticated man about town and a high rolling gambler when he traveled. His travels included New York City, Europe and the Middle East. He even purchased a ticket for the maiden voyage on the Titanic; luckily for him, however, he had to return earlier and did not go on the doomed voyage. Hershey's mother, a daughter of affluent Swiss immigrants, was a prominent influence on her son until her death in 1920. She belonged to the Reformed Mennonite Church whose members were even stricter in their beliefs and moral code than the mainstream Mennonite Church. Children however, were not automatically part of the church unless they decided to join it. By all accounts, Hershey did not join his mother's church, yet in his company town in Pennsylvania, saloons were outlawed and Sabbath observed. In 1898, he married Catherine Elizabeth Sweeney who was fourteen years his junior. Kitty, as she was known to family and friends, died of a debilitating muscular disease at age forty-two in 1915. He never remarried. In 1916, he visited Cuba accompanied by his mother and his aunt. At the time, Cuba was a magnet for those who, like Milton Hershey, enjoyed playing golf, gambling and betting on race horses.

\section{Cuban - American Relations at the beginning of the Twentieth Century and the Sugar Industry}

By the time Hershey came to Cuba, many Americans saw it as a land of opportunities in the same way as many Spanish immigrants had done for several generations before. Cuba's independence from Spain was finally achieved in 1898 after more than two decades of wars that had started in 1875. The war had devastated the Cuban countryside and destroyed many centrales, sugar mills and plantations operated by Cuban sacarocracia, Spanish and Cuban landowners of the nineteenth century. The Cuban anthropologist Fernando Ortiz ${ }^{4}$ defined central as follows:

The central is now more than a mere plantation; there are no longer any real planters in Cuba. The modern central is not a simple agricultural enterprise, nor even a factory whose production is based on the raw material at hand. Today it is a complicated "system of land, machinery, transportation, technicians, workers, capital, and people to produce sugar." It is a complete social organism, as live and complex as a city or municipality, or a baronial keep with its surrounding fief of vassals, tenants and serfs. The latifundium is only the territorial base, the visible

4. Fernando Ortiz, Cuban Counterpoint: Tobacco and Sugar, trans. Harriet de Onís, introduction Bronislaw Malinowski, Prol. Herminio Portell Vilá, new introduction Fernando Coronil (Durham: Duke University Press, 1947/1995), 52. 
expression of this. The central is vertebrate by an economic and legal structure that combines masses of money, all in proportion to the integral scope of the huge organism for sugar production.

As is well known, the United States massive military intervention played a pivotal role in Cuban's independence. In the first years after its independence from Spain, Cuba was directly governed by an administration appointed by the United States Congress. In 1902, power was officially transferred to a Cuban government but with conditions imposed by the infamous Platt Amendment to the Cuban constitution that defined the US-Cuban relationship through 1934. The Platt Amendment created favorable conditions for American businesses and stimulated a quick growth of American-owned sugar estates. The US boom in Cuba at the beginning of the twentieth century was seen by many as a hostile takeover conducted at bargain prices. The sugar frenzy of the first decades of the twentieth century anticipated the rise of the casino and tourist industry that came later. Surely, Hershey was aware that American investments in Cuban sugar production were paying off. At the same time, European production of sugar was severely disrupted and reduced from nine million tons per year to less than four million, as World War I was still fought in Europe. The Cuban sugar industry, now mainly administrated from Wall Street, determined and dictated world sugar prices. Unbridled sugar speculation during the so-called period of vacas gordas, fat cows, generated a bubble of immense prosperity that exploded when the world sugar market crashed in 1920. Hershey purchased several plantations that had been burned by the Revolutionary Army and never recovered from the devastation of the protracted war. He immersed himself in the Cuban sugar business by developing his real estate holdings there and also by actively buying sugar futures. When the sugar market crashed in 1920, he bore significant losses because of the sugar speculations.

\section{Findings}

\section{Milton Hershey in Cuba}

An astute businessman like no other, Milton Hershey realized that manufacturing his own sugar would allow him the privilege and freedom of controlling two thirds of the raw supplies for his chocolate production. From the inception of his chocolate business, the abundance of milk in Pennsylvania dairy counties had been a major reason for building the factory in Derry Township, now known as Hershey. Controlling the production of cocoa beans was more complicated as the Hershey chocolate formula required a mixture of cocoa beans that came from several too far away geographical regions such as Java, 
Venezuela, Granada, Trinidad and Ceylon. The development of Cuban operations started promptly in 1916 and within a few years, Hershey built a complete-cycle sugar production in an area conveniently located between two major Cuban ports, Havana and Matanzas, some forty miles east of the capital. To accommodate the needs of his work force, Hershey built a well-organized company town in the midst of the Cuban countryside. A hotel, a golf course and a school for orphaned boys followed shortly. A fascination with Cuba, wellknown for its easy ways with gambling and entertainment, a business vision and a desire to control sugar supply were the driving forces that moved his tropical enterprise.

A lack of suitable roads and transportation had been a significant factor that had kept these areas out of the radar of sugar producers prior to Milton Hershey's arrival. Railroads, the main mode of transportation on the island since the 1840s, were laid too far to the south. Hershey's energy and bold imagination soon converted the area into a thriving landscape dominated by a modern sugar mill, a char-bone refinery that was added in 1924, an electric railroad and a model town, batey. The railroad was designed to serve the needs of Hershey sugar production such as the transportation of sugar cane and of sugar and also as an important connection between Havana and Matanzas, two major Cuban ports. Sugar was carted via rail to ferries that brought it to Key West from where it followed its railway journey to Pennsylvania on the Florida Overseas Railroad. The latter was in operation from 1912 to 1935 when it was destroyed by the Labor Day Hurricane. With a certain degree of success, the Hershey railroad in Cuba continues functioning to this day.

The gigantic modern mill equipped with the best available technology was completed in 1919. Equipment for the construction of the mills and batey was purchased from the US Army Corp of Engineers that had just completed the construction of the Panama Canal. It was the most modern and advanced machinery for the time. All cargo arrived at the conveniently located port of Santa Cruz del Norte, just a few miles away. The proximity to the coast was another important factor in making the construction project there feasible. Over the next few years, Hershey continued buying land and sugar mills in the vicinity. He acquired the plantations Lotería, Nuestra Señora del Carmen, El Conde, Río Blanco, San Matías and San Francisco. The Central Hershey, Hershey Sugar Mill, started operations on March 20, 1919..$^{5}$ In a symbolic gesture, Milton Hershey himself started the electric engine that moved the mill. During the first zafra, cane harvesting period of 1919, the Central Hershey employed about a thousand workers.

5. I am following Ribot Enríquez's dates (Amarilys Ribot Enríquez, Hershey (La Habana: Unicornio, 2008), 30)), while according to D'Antonio (Hershey: Milton Hershey's, 170), the mill at Hershey, Cuba started grinding in January of 1919. 
Hershey's assets in Cuba do not seem to be that significant if one compares them to such giants as the Cuba Cane Sugar Corporation with an authorized capital of $\$ 50$ million in 1915, the Cuban-American Sugar Company, which followed it with two and a half times less the capital, and the Punta Alegre Sugar Company with $\$ 3$ million. Hershey's imprint in Cuba, however, goes far beyond the sugar mills, a refinery, a model town and more than a hundred miles of railroad. Interestingly, the beginning of Hershey operations in Cuba coincided with the opening of a rum distillery by the Arechabala Rum Company in close proximity to the Central Hershey in the nearby town of Santa Cruz del Norte. On March 30, 1919, the same month that the Hershey mill produced its first batch of raw sugar, a rum distillery started producing rum a short distance away from batey Hershey. The two plants were conveniently connected by the newly built railroad. The Arechabala Company had started in 1878 in Cárdenas as the producer of aguardiente, a term loosely used in Spanish-speaking countries for all alcohol and spirits. For many, the production of sugar and rum are closely knit together. Historically, even small mills in Cuba produced home-made alcohol as a way of utilizing molasses, a by-product of sugar production. Those beverages, however, were not of commercial quality and could not compete with rums coming from the English-speaking Caribbean where rum production had been perfected since the 1600s. Two reasons are usually offered as an explanation for the absence of commercial rum production in the Spanish Caribbean. As the industry was dominated by the French and British experts, the Spanish colonies lacked the know-how for commercial rum production. The other reason was Spain's frowning on the moral consequences of alcohol consumption and the protective desire to promote its own wines. Cuban rum successfully entered world markets only towards the end of the nineteenth century when Facundo Bacardí in Santiago and José Arechabala in Cárdenas opened their distilleries and developed their own formulas.

The main ingredient for rum production is molasses, a by-product of raw sugar processing. It is a dark brown liquid that is left over after the crystallization of sugar. If not used for rum or technical alcohol, it may be sold for culinary purposes or added to cattle feed as a source of vitamins. In her history of Hershey, Cuba, the Cuban researcher Amarylis Ribot-Enriquez ${ }^{6}$ points out that the original Arechabala distillery in Santa Cruz del Norte was built as a still for Hershey molasses. Incidentally, Prohibition was instituted with ratification of the Eighteenth Amendment to the United States Constitution on January 16, 1919. During Prohibition, Cuba's capital Havana became a drinking and gambling haven for Americans who could afford the ferry ride from the Florida coast to the drinking paradise of Havana. No wonder that the Bacardí advertisement promised American tourists "Flying to Heaven with Bacardi." Rumors about Arechabala's involvement with $\mathrm{Al}$ Capone and a direct supply of American

6. Ribot Enríquez, Hershey, 32. 
yachts from the sea-shore facility in Santa Cruz del Norte continuously circulated in Cuba. ${ }^{7}$ Clearly, Milton Hershey who frowned upon alcohol consumption in Hershey, Pennsylvania would not openly be involved with the production of rum, yet oral interviews with Cuban employees contained in Paul Wallace's unpublished collection at the Hershey Community Archives indicate that the Santa Cruz distillery used molasses from the Hershey mill. ${ }^{8}$

This story had interesting consequences over time. In the 1930s, the Arechabala Company registered the trademark Rum Habana Club. In 1960, after the Cuban revolution, the Arechabala assets and distillery were "nationalized;" plainly speaking, they were confiscated without any compensation. During the first ten years of the new regime, tourism and casino-style entertainment were frowned upon by the Cuban government who saw them as vestiges of imperialist oppression. Since the 1970s, however, revolutionary rhetoric of the authorities has changed and they not only embraced foreign tourism, but have been heavily promoting the rum Habana Club as the Cuban national drink and a primary product of Cuban export. It is marketed through a Cuban-French joint venture with Pernod Ricard and is sold in one hundred twenty countries except the United States. Havana Club and cocktails made with it are a major tourist attraction at hotels and restaurants in Havana. Ernest Hemingway's famous "my mojito in La Bodeguita, my daiquiri in El Floridita" referring to two now famous restaurants is a ubiquitous advertising line in today's Cuban tourist industry. The largest Habana Club rum distillery on the island, pompously opened by Fidel Castro himself, is currently located on the site of the original Arechabala facility at Santa Cruz del Norte joined at birth with the Central Hershey.

The sugar that we consume requires a two-cycle process. First, raw sugar is extracted from sugar cane at sugar mills, after which it can be further refined for use in confectionary and as a consumer product. Sugar production is also seasonal. When cane is ripe and ready it has to be processed in a matter of days, otherwise the cane may get spoiled by bacteria and fungi. Raw sugar can be transported and refined without the rush of cane processing; for this reason, mills are operating only during the harvest periods, while refineries can work year round. The plants at Central San Juan and Central Hershey produced more than 30 million pounds of raw sugar in 1920, but this figure fell far short of what the chocolate factory needed. ${ }^{9}$ Looking for more property, Hershey bought a steam-powered mill that came with lush gardens and an old hacienda called Rosario. It soon became his favorite residence in Cuba and there he built a school for orphaned boys in the same fashion as he had done in Pennsylvania. In the

7. Author's interview with the historian Zoila Lapique Becali, Habana, November 8, 2012.

8. Paul Wallace, Paul Wallace Research Collection. Hershey Community Archives. Accession number: 97004. Box: B9. Folder: 32.

9. D’Antonio, Hershey: Milton Hershey's, 172. 
meantime, the US lifting of price restrictions on raw sugar in 1919 resulted in a frenzy of market speculation now known as the "Dance of the Millions." Within a few months, the price of raw sugar rose and fell dramatically, ruining hundreds of planters and merchants in the process. Hershey, an ever avid gambler, had purchased futures contracts and lost millions when the price of sugar fell from twenty three cents per pound that he had paid to less than four cents per pound. Yet despite these losses, Hershey managed to survive this crisis and between 1921 and 1923, Hershey chocolate sales increased by about thirty percent. ${ }^{10}$

At the beginning of its operations, Central Hershey only produced raw sugar and shipped it to the United States for refining. In 1924, a modern refinery that used the char bone whitening technology was added. The eight story refinery operated until it was shut down together with most of the Cuban sugar industry in the first decade of the twenty-first century. Today it still dominates the surrounding landscape and gives the town of Hershey, Cuba its distinctive landmark look in the same way as the chimneys of the chocolate factory in Hershey, Pennsylvania define their town. As sugar production in the 1920s was on the rise, a new mill was added. The amplification and new equipment installed in 1924 allowed for the production of eighteen thousand bags of one hundred pounds of refined sugar a day. ${ }^{11}$ During zafra, the harvesting period that usually lasted for about four months, the mill employed up to eighteen hundred workers. The amount of raw sugar produced by all operating mills allowed for another five to six months of refinery operation. Slowly but surely, Hershey acquired several adjacent centrales that allowed for a steady flow of raw sugar to the refinery so that it could stay in business for five to six months after the zafra was over. Among many novel ideas, Hershey introduced the transportation of sugar bags on carts similar to those in which ore or coal were moved at the time. This innovative mode of transportation replaced the traditional Cuban 325pound bags that required relatively expensive man power to move.

By 1925, the electric power plant and the railroad served not only the central but adjacent towns. In the winter of 1925-1926, Cuban railroad workers made an attempt at organizing a union and demanding wage increases. Hershey resisted viciously. The Cuban newspaper El Diario published his response to the employees' demands on January 19, 1926, "Mr. Hershey will not submit to direction from labor union delegates and if he is obliged to satisfy the wishes of the workmen then he will end his business in Cuba and carry on no more improvements."12 Apparently, nobody could dictate to Hershey how to spend his money or spread his wealth. His vision of happiness for his workforce did not go beyond building a model town for his workers and providing them with services that he saw fit. When the labor conflict, which actually was part of a larger-scale

10. D'Antonio, Hershey: Milton Hershey's, 176.

11. Ribot Enríquez, Hershey, 31.

12. D'Antonio, Hershey: Milton Hershey's, 188. 
labor union struggle in Cuba at the time, was resolved with a ten percent raise, he stopped the annual profit-sharing plan. According to D'Antonio, ${ }^{13}$ organizers who had been fired were never allowed to return to their jobs. Without doubt, Hershey handled his affairs in Cuba in a paternalistic way. He was determined to build his heaven on earth that would allow him to exercise complete control of his work force. He built schools and he brought American technology and even American cattle to Cuba. Demonstrations of advanced agricultural techniques and country fairs similar to those popular across the United States in the fall attracted visitors from far away due to the convenience of railroads. In 1927, the country fair hosted the Cuban president Gerardo Machado who delivered a speech. The program included demonstrations of new equipment shipped from the United States and showcased prize vegetables, thoroughbred horses and milk cows that were delivered from Pennsylvania.

\section{Social Impact on Cuban Soil}

In 1926, the company owned 1575 caballerías of land, which is equivalent to 52,230 acres and more than a hundred miles of private railroad. ${ }^{14}$ Hershey's commercial independence-he never entered into an alliance with any of the sugar giants that operated on the island-allowed him to recover from the losses incurred both by the sugar crisis of 1920 and the Great Depression of 1929. In 1927, Hershey's assets were organized in three major companies: The Hershey Chocolate Corporation that made and marketed chocolate consumer products; Hershey Estates that operated service such as electric power, water and sewers, trolleys, retails, real estate, including Hershey Park and served the town of Hershey in Pennsylvania, and the Hershey Corporation that managed all things Cuban. All things Cuban included a town that provided housing for those who worked at his enterprises and not surprisingly was named after its owner/benefactor. Hershey, Cuba had comfortable living quarters, education and recreation facilities, and reflected in a lush tropical setting the idealism of its owner/designer who had first implemented it in Pennsylvania. His efforts were constantly praised by the Cuban press. Ribot Enríquez ${ }^{15}$ quotes an article from Diario de la Marina, an influential Cuban newspaper of the time: "Like in the United States, Cuban Hershey has the same comfortable and beautiful homes; a magnificent hotel built of stone; a ballroom; an agricultural and a public school; ball stadium; and a big department store. All that in a beautiful tropical setting, with magnificent parks and gardens." 16 The paternalistic overtones and a fascination with the North American way of life are transparent in this praise.

13. Ibid., 189.

14. Ribot Enríquez, Hershey, 32.

15. Ibid., 35.

16. Translation is mine. 
Hershey, Cuba was a planned community of individual housing that expanded horizontally in strict geometrical patterns. More luxurious stone bungalows with French tile roofs for upper management were built in the northern part of town, while modest wooden family houses for permanent employees were to the south followed by what is called now "el batey sur," southern village, with smaller housing for two families called duplexes. These were designed for those who were paid less, and who incidentally were mostly Afro-Cuban. As was customary in the Cuban sugar industry of the time, many low-wage workers were migrants. They came from the nearby Caribbean, such as Barbados, St. Lucia, Jamaica and San Vicente, and from as far away as the Spanish Canary Islands. A dormitory, popularly known as el barracón, was built to accommodate single men who were seasonal workers. Yet even these buildings, in the same way as their prototypes in Pennsylvania, had distinct architectural elements that broke the monotony. All housing had running water, toilets and all necessary amenities. The idealistic owner wanted his employees to be healthy and content. He even incurred significant additional expenses building his factory and town up on the hill against the advice of his counselors. Down in the valley the mosquito infestation provoked illnesses such as malaria and yellow fever.

A golf course, praised as one the best in the country, and a stone hotel with a bar and restaurant opened in 1920. In the same way as in Pennsylvania, tourism was encouraged, and for a total price of four dollars, visitors could ride from Havana on Hershey railroad, enjoy a lunch at Hershey hotel, visit the mill and play golf at the nearby golf course. They could also stay overnight at the hotel where each room was equipped with a private bath. A movie theater, a department store, a doctor's office, an ice factory and a ballroom were among the valuable amenities of the town. Improvements and additions were constant during the first years. In 1926, new offices and a larger department store were added. The interior of the store was decorated with caoba furniture and decorative tiles. The store was also equipped with the most modern system of cashier's registers that are ironically in use even today. Towards 1924, there was a Sport Club, a hippodrome with stables, a garbage dump, a slaughtering house, a dairy and a creamery. Like other towns built around chocolate factories by their owners, such as Cadbury's Bournville in the UK or Suchard's Cité Suchard in Switzerland, both Hershey, Pennsylvania and Cuba, were, to quote a contemporary urban critic, "a curious blend of idealistic vision and pragmatic company town - the convergence of paternalistic benevolence and capitalist expedience."17 There is no doubt that Milton Hershey, just as all other great philanthropists of the time, believed that improving the welfare of his staff would lead, ultimately, to a more profitable business. After Hershey's death in

17. Nicola, "The Towns that Chocolate Built," Edible Geography. May 11, 2013. http://goo.gl/WnLb4m. 
1945, Cuban holdings were sold in 1946 to the Cuban Atlantic Sugar Company. At the time of the sale the operations included 60,000 acres of land, five raw sugar mills, a peanut oil plant, a henequen plant, four electric plants, and 251 miles of railroad track with sufficient locomotives and cars.

As of November 2012, when the author visited Hershey, the railroad continued to be a major means of transportation in the area even though there was no set schedule and no information when to expect the train. Single family homes surrounded by lavish tropical vegetation lined the streets. The mill and the refinery had been abandoned several years ago and were in a state of complete ruin and disrepair as were the hotel and other community buildings. The doctor's office and the pharmacy were operating in the same facilities as almost a hundred years ago. Their conditions were hardly improved since their opening in 1920. The department store has been used as a point of distributing provisions according to the Cuban rationing system which has continued since the "triumph of the revolution" in 1959. It still boasts beautiful tiles, lavish caoba decorations and functioning cash registers. The infamous barracón, a dormitory for single workers, hosted several families. The town is now called Batey Camilo Cienfuegos in honor of the famous revolutionary hero. Yet for the purpose of attracting tourism, the railway station is still called Hershey and efforts are made to bring foreign tourists and to provide them with entertainment at Hershey Gardens, a resort-like park a short distance away from the ruins of the Sugar Town.

\section{Nostalgic Recreation of the Tropical Paradise Back Home}

Building a luxury hotel near Hershey, Pennsylvania was on Milton Hershey's agenda for a long time. A businessman keenly aware of the impact of advertising and marketing, he encouraged customers' curiosity and offered tours of his factory and town from the early onset of its development. Hershey admitted that he had planned to build a hotel on a hill overlooking his multiple properties for a very long time. His initial plan was to build a hotel reminiscent of a luxury hotel in Egypt where he and his wife had once stayed. Reportedly, many, including his mother, criticized and ridiculed his initial plans for a luxury hotel amongst Pennsylvania cornfields. Yet at the time of the Great Depression with Cuban enterprise bringing steady profits and his mother long dead, Hershey decided that it was time to fulfill his fantasy. The chosen style in accordance with the vogue of the time was Spanish Colonial Revival. Built at the time of the Great Depression, with the profits brought in by the Cuban sugar production, the Hotel Hershey allowed creating new jobs and served the clearly defined purpose of attracting more tourism to Hershey. Even today the lobby of the Hotel Hershey bears a resemblance to the acclaimed Plaza Hotel in Havana where Milton Hershey used to stay while in Cuba. The overall design of the hotel created an illusion of exotic tropical ambiance in the midst of Pennsylvania 
cornfields. The vast indoor patio was and still is covered with a ceiling painted as the bright blue sky of the tropics and boasts a fountain adorned with colorful tiles. Palm trees, birdcages and a painted mural with a seaside scene in the Caribbean further intensified the illusion of an outlandish landscape. Long before Walt Disney came up with the Pirates of the Caribbean ride in his entertainment park, long before Las Vegas hosted pink flamingoes and fake Venice canals, the Hotel Hershey boasted its own version of exotic tropics on a hill in rural Pennsylvania. The construction was finished between 1931 and 1933. The style that became known as Spanish or Mediterranean Revival had gone through several stages of evolution. In the late nineteenth century, Santa Fe railroad stations were built in what became known as Mission Revival style. In 1915, the Panama-California World Fair in San Diego was adorned with flamboyantly decorated neo-baroque pavilions. Public buildings, Grand hotels on Florida beaches and even storage facilities soon followed. Two major reasons for the success of the highly ornamented style are usually offered. On the one hand, the climate in the South and Southwest of the United States, in Florida, Texas, New Mexico, Arizona and California seemed to be appropriate for a Mediterranean lifestyle. At the same time, the conquest of the new frontiers and lands west of the Mississippi prompted a need for a suitable national narrative and a search for a usable past in the new states as they were absorbing more and more non-native population.

The construction of the hotel was entrusted to David Paul Witmer (18941981), a native of Elizabethtown, whose education was limited to three-years of training at Stevens Trade School in Lancaster. By the time Hershey hired him in 1924, Witmer had earned certification as a professional engineer and registered architect. Hershey, whose formal education ended in grammar school, must have recognized and respected Witmer's talent as one of his own kind. Witmer not only managed Hershey's construction enterprise, he later served on several Hershey corporate boards and was appointed Superintendent of the Hershey Industrial School. For the interior design of the hotel, they hired Robert von Ezdorf whose credentials included the grandiose Commodore (1919) and Waldorf-Astoria Hotels (1931) in New York City. At the time of the Great Depression, the Hotel Hershey was not the only one built with opulence and fascinating decor. The Hotel Hershey followed in the path of the mythical Waldorf-Astoria built in the 1890s. The Waldorf-Astoria redefined public spaces in America from the moment it opened as it became a gathering and entertainment place for the city's and the world's elite. A hotel was not any longer a space to look down upon, but a center for social life and recreation. The original Waldorf-Astoria was demolished in 1929 to give way to the Empire State Building, yet the legend of the Waldorf-Astoria lived on as a new building with the same name rose and opened on Park Avenue. It should be noted that the nostalgic recreation of yesteryear opulence that the Waldorf-Astoria boasts even today never achieved the mythological status of the original hotel. The newly 
built Waldorf-Astoria must have been quite a reputable credential for hiring one of its interior designers. An architecture critic, Justin Kaplan, ${ }^{18}$ calls hotel decorators of the time "theatrical set designers at heart. Like D.W.Griffith and Cecil B. DeMille a little later on, they provided the culturally untraveled with adventure, visual thrills, a sense of history, and something of a museum and amusement park experience." Von Ezdorf arguably belonged to this breed of designers. At Hershey, he created a light-filled illusion of a Caribbean/Cuban space complete with a painted blue-sky ceiling, obligatory balconies, a fountain decorated with colorful tiles and birdcages with live birds whose chirping complemented the illusion of the tropics in in the middle of Pennsylvania winters.

Illusion and theatricality lie at the heart of the Spanish/Caribbean/ Colonial decor of many public buildings in this style. There are several ways that help to achieve the effect of transplanting a visitor into a tropical space upon entry. Lighting, texture, color and sound all work together to create the effect of tropical indulgence in rural Pennsylvania. Von Ezdorf's illusionist style and skills were best illustrated by a mural, entitled Hispanola (sic) that adorns what is now called the Iberian lounge. Built during the time of Prohibition, this space was initially unveiled as a reading room, but since 1968 it is used as a bar. A wine cellar and a cocktail lounge were opened shortly after Prohibition was lifted in 1933. Hispanola probably invokes the island of the same name shared by Haiti and the Dominican Republic, yet it may as well be a fantasy in the vein of any Caribbean colonial space. The fantasy landscape is replete with a remote sailboat, colorfully dressed local women, palm trees and walls painted in a stripe pattern. The stripes evoke Moorish architecture of the famous mosque in Córdoba, Spain. The mural contains an optical illusion known since the Renaissance, whereby a tile path in the middle of the mural leads the viewer towards the waterfront. No matter where the viewer stands, the path is always in front of him. The illusion of movement towards the sea is achieved by showing most figures from the back in such a way that it seems that they too are looking and moving towards the waterfront.

The designer created continuity in the overall decor of public spaces of the hotel and of the mural. The whole public space of the hotel evokes a stage set where the waterfront in the mural serves as a backdrop. A tile path takes one from the Fountain Lobby to the mural that opens into the open sea. The balconies of the Fountain Lobby, wrought iron lamps, exquisite tiles, the fountain in the center and palm trees seem to complement the mural. Spanish Revival architecture is characterized by abundant and, if possible, natural lighting. The Fountain Lobby is lit with openings that allow daylight in and reflect on the colorful tiles by a famed California designer Ernest Batchelder, one of the

18. Justin Kaplan, When the Astors Owned New York: Blue Bloods and Grand Hotels in a Gilded Age (New York: Viking, 2006), 86. 
masterminds of the acclaimed Arroyo culture. As California historian Kevin Starr ${ }^{19}$ puts it, Batchelder "designed and produced a breathtakingly lovely series of ceramic tiles used in home decorations. Whenever possible, Batchelder employed Southern Californian motifs in his creations (an art nouveau swirl of vines, flowers, oak trees) and bright Southern Californian colors (brown, blue, apricot, yellow)."

The texture and colors of Batchelder designs, born in California for the Hotel Hershey in Pennsylvania, coordinated perfectly with the path towards a painted waterfront and a painted blue-sky ceiling. To emphasize the illusion of an old Spanish patio, beams were made out of oak wood that had soaked under water for a half century at the old Swatara Creek Dam..$^{20}$ Architectural details, carved out of aged native wood by the skilled members of the construction team created an inauthentic fantasy of old Spain in the Caribbean or of the Caribbean in Pennsylvania depending on how one wants to see it. Marble shipped from the Baumgardner Company of Baltimore, Maryland, and cut on location added an Italianate taste to the almost theatrical decoration. Given the necessity of artificial lighting during winter, the lobby was adorned with numerous wrought iron lamps that may be more appropriate to decorate a stage set for a Spanish Golden Age drama. In this sense, the Hershey Hotel in its theatricality is akin to other hotels built at the time such as Don CeSar Hotel on St. Pete's Beach in Florida, also known as "Pink Palace." Incidentally this hotel was named after Don César de Bazan, a character from the eponymous opera by Jules Massenet based on a drama set in Spain by Victor Hugo. The sound of a water fountain similar to those that can be seen in many Latin American towns and the chirping of birds in the birdcages on the balconies complemented the resulting tropical fantasy. Milton Hershey's hotel of choice in Havana, the famous Plaza, still has a similar tiled fountain and lavish greenery in its lobby.

The overall illusionistic design invited the visitors to be part of a show, set in a remote and simultaneously near-by tropical space. The design of the Hotel Hershey in 1933 preceded what Disneyland and Las Vegas would do to American imagination decades later. D. J. Waldie ${ }^{21}$, in an essay about Spanish Colonial Revival in California, notes that California architects "understood that the Spanish Revival was an imagined tradition, a synthetic style, that it was as inauthentic as it was appropriate." These words reflect what von Ezdorf achieved in Hershey. Paradoxically, as Milton Hershey chose to look back at the imaginary past and outlandish landscapes of the tropics, he looked into the future where he always wanted to be. The Hotel Hershey is currently included in the list of

19. Kevin Starr, Inventing the Dream (New York: Oxford University Press, 1985), 109.

20. "Hotel Hershey," Hershey Community Archives. May 11, 2013, http://goo.gl/ gn52xjy.

21. D. J. Waldie, "Casa del Herrero," California Romantica (New York: Rizzoli, 2007), 204. 
Historic Hotels of America by the National Trust for Historic Preservation. Hershey is quoted to have said at the opening of the Hotel Hershey that his intention was "to utilize nature's beauty for the pleasure of men."22 In his quest for pleasure derived from "nature's beauty," he joined many builders in Florida and California, where the Spanish and Mediterranean Revival shaped both public and private spaces, such as museums, churches, hotels, movie theaters, storage facilities and homes.

\section{Conclusion}

An American-style company town in Cuba and an Iberian-themed hotel in Pennsylvania are uncannily connected; both served as monuments to the United States' imperial power in the Caribbean and were a nostalgic reminder of pleasures associated with the colonial paradise of the tropics. These pleasures often involved alcoholic beverages. The selling of molasses manufactured at the Hershey sugar plant to a rum refinery near-by had social and historical consequences that Milton Hershey could have hardly foreseen. Back home, the construction of the Hotel Hershey crossed boundaries in time and space and went far beyond tropical nostalgia. A shrewd businessman, Milton Hershey anticipated that a tropical fantasy that he envisioned on a hill in Pennsylvania would look into the future for decades to come. A search for the (a)historic past and exotic outlandish landscape created a local future as the hotel has stood the test of time. The illusionistic design with a ceiling painted as a blue sky of the tropics and a tile path leading to the seashore did not only respond to the playfulness of the Spanish Colonial Revival style, but for Milton Hershey it was a transgression; a rebellion against the Mennonite upbringing by his mother; a monument to his deceased wife who had shared his travels, and a reminder of the short-lived joys and pleasures of life, as well as another successful business enterprise in the foundation of which lay the profits from Cuban sugar.

\section{Bibliography}

D'Antonio, Michael. Hershey: Milton Hershey's Extraordinary Life of Wealth, Empire and Utopian Dreams. New York: Simon \& Schuster, 2006.

"Hotel Hershey." Hershey Community Archives. May 11, 2013, http://goo.gl/ gn52xjy.

22. "Hotel Hershey," Hershey Community Archives. 
Kaplan, Justin. When the Astors Owned New York: Blue Bloods and Grand Hotels in a Gilded Age. New York: Viking, 2006.

Nicola. "The Towns that Chocolate Built." Edible Geography. May 11, 2013. http://goo.gl/WnLb4m.

Ortiz, Fernando. Cuban Counterpoint: Tobacco and Sugar. Translated by Harriet de Onís, with Introduction by Bronislaw Malinowski, Prol. Herminio Portell Vilá, and New Introduction by Fernando Coronil. Durham: Duke University Press, 1947/1995.

Ribot Enríquez, Amarilys. Hershey. La Habana: Unicornio, 2008.

Starr, Kevin. Inventing the Dream. New York: Oxford University Press, 1985.

Waldie, D. J. "Casa del Herrero." California Romantica. New York: Rizzoli, 2007.

Wallace, Paul. Paul Wallace Research Collection. Hershey Community Archives. Accession number: 97004. Box: B9. Folder: 32. 